\title{
Incarnation theology versus the sacralisation of authority
}

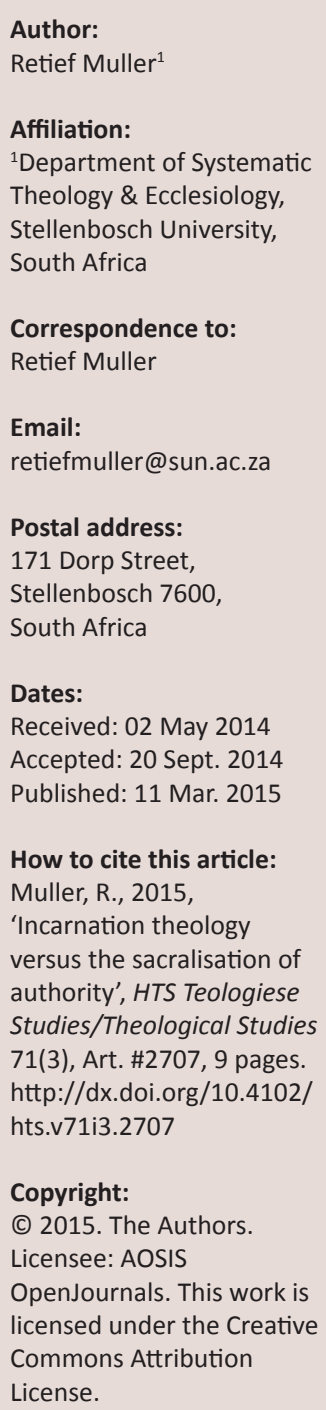

Read online:

Scan this $Q R$ code with your smart phone or mobile device to read online.
This article juxtaposed the theological theme of incarnation with quasi-religious invasions of public power structures and institutions in southern Africa, which has been described by the term sacralisation of authority. Incarnational theology as constructed on the model of the Incarnation of Jesus Christ concerns a Divine-human border crossing from above to below or from power into powerlessness. Sacralisation of authority concerns an opposite process whereby mundane structures and people of power seek to bolster their authority even further by the acquisition of godlike attributes. This article referred to political realities in southern Africa, particularly in Zimbabwe and South Africa as illustrative of the latter, whereas the Tshwane Leadership Foundation - a non-governmental organisation (NGO) operating in Tshwane's inner city - served as a case study in incarnational theology of the grassroots.

\section{Introduction}

This article attempts to place certain recent institutionalised assertions of religiosity or quasireligiosity in the southern African public arena in a theological perspective by contrasting these more publicised stories with a different kind of story of how religiosity can and does engage public life with credibility from below. I label the former sacralisation of authority and power whereas the alternative case is described along the lines of incarnational theology. The types of religiosity under discussion are either Christian or derived from Christianity.

Therefore, in addition to making a theological point regarding the relationship between Christianity and society and how the one should relate to the other, this article is also a preliminary attempt at documenting some of the ways in which contemporary southern African Christian history might be seen to diffuse itself beyond the traditional parameter of institutionalised Christianity. For this latter purpose I employ a first person narrative style to describe the ministry of the Tshwane Leadership Foundation (TLF), and my interactions with some of their members. In terms of methodology, this style aims to reflect and prioritise the personal narratives perceived in the accounts of TLF participants regarding their lived experiences of incarnation theology on the streets of the city. What occurs here might be further termed a grassroots, lay, or even a street theology. It might also be described as a bottom-up rather than a top-down theology, which is to say that this does not concern academic theologians reflecting about God and humanity in a systematic way, but rather activists and ordinary, yet socially engaged, individuals living out their understanding of the Christian faith within the context of contemporary urban South Africa. A narrative style is best suited for allowing these voices on the ground to 'speak' regarding their emerging theological paradigm. An important implication for academic theology arising out of all of this is that Christian history might increasingly be eclipsing church history if the latter is defined as preoccupying itself exclusively with the church as institution.

\section{Incarnation as a position of vulnerability}

'Only a suffering God can help ...': Elizabeth A. Johnson describes how post-Holocaust political theology such as exemplified in the work of Moltmann (1993), Soelle (1984), and others, heeded and further developed this profound insight of Dietrich Bonhoeffer, which he had written down in his prison cell (Johnson 2011:56). Incarnation theology, which proceeds from the central understanding of the God of Christianity as the crucified one had various further 'incarnations' in the 20th century, and although they are not all the same or even similar, feminist, liberation, black and ecological theology are all extremely serious about incarnation as a theological theme. If one has to name one example of a book that manages to address several different aspects of incarnational theology, it would be difficult to look beyond the evocatively titled classic by Kosuke Koyama, Water buffalo theology, which also addresses the subject of interfaith dialogue (Koyama 1999).

What has this to do with South Africa after 20 odd years of democracy? The context could not be any further removed from either Koyama's East Asia, or Soelle and Moltmann's late 20th century 
Germany. We are certainly not in a post-Holocaust situation in South Africa. Nevertheless, it is clear that apartheid has left an ugly scar on our societal landscape and therefore it seems obvious that Bonhoeffer's perspective would be an equally good theological starting point for us. Without such radical recognition of the implications of incarnation our present societal impasse will remain. By way of an example of this impasse: at a recent consultation at the University of Pretoria on Social Cohesion and Reconciliation (22-23 August 2013) one of the participants asked an intriguing question, which as far as I know remained unanswered for the duration of the conference. The question was whether in South Africa it would not make better sense to forego talk of reconciliation and search for other vocabulary, because in order for people to reconcile with one another the premise is that they were at one stage in a peaceful, stable, equal relationship. 'When were we in South Africa ever in such a relationship?'.

Of course, the imago Dei as a theological concept might provide an answer to the effect that, even if we did not realise it, even if one group consistently oppressed and at times attempted to dehumanise others, we were in fact created to be equal, and therefore reconciliation is an imperative. Although the concept of imago Dei is a disputed and much complicated notion, especially within a historical context of post-Darwinian insights into human evolution and more comprehensive understandings regarding our relatedness to other animals, Edinburgh theologian David Fergusson has argued that one way in which this key theological idea might be usefully considered is in the 'eschatological sense in which Christ is the image of the people we shall become' (Fergusson 2013:452). This is a positive contribution with an eye to the future and faith in the coming kingdom of God, but still in real historical terms the question about South Africa's fundamental inequality and dividedness will not disappear so simply.

One further theological response to this dilemma might be to de-emphasise talk of reconciliation and engage instead in reflexive incarnational theology. It seems to me that the incarnation serves as an unsurpassed model for embodying these themes: God becoming human in Christ is the ultimate affirmation of human dignity; it is also emblematic of the most profound border crossing, stripping down the barriers between divinity and humanity, transcendence and immanence. The conflicting loyalties of different interest groups are exemplified in the interspersed narratives, which constitute the biblical descriptions of the life, death, and resurrection of Jesus.

According to Frederick Aquino (2000:41), 'the incarnation reveals the extent to which God attempts to restore dignity and honor to human personhood'. However, this point of view implies a somewhat dispensationalist view that human dignity had somehow evaporated prior to the life of Jesus, which is an idea that cannot be countenanced if one wishes to affirm a wider more 'diffuse' understanding of imago Dei more generally 'as a signifier of the human condition before
God ...' (Fergusson 2013:451-452). Therefore, the incarnation does not restore human dignity. Rather it confirms the already existent, but masked dignity of humans in relation to God. The incarnation affirms a spirituality of relationality, as elaborated on by contemporary commentators on the issue of human dignity such as Archbishop Emeritus Desmond Tutu (Battle 2009) and German theologian Christoff Schwöbel (2006:44-58) amongst others.

The 'suffering God' of Bonhoeffer might imply a radical incarnation. What is meant by radical incarnation? It means that a suspension of orthodoxy might be required to truly see God. According to Delwin Brown (2006), theologians of the early church found it difficult to comprehend the:

... paradoxical idea that the transcendent, omnipotent God could truly suffer and die. They resolved the paradox by saying that God does not truly suffer. Radical incarnationism resolves the paradox the other way: the God who does not suffer is not truly God (p. 301)

Although I agree with this understanding of God, I would disagree that paradox is resolved by this. Neither should it be. Rather paradox itself is highlighted as an essential characteristic of the Christian mystery. It is not of little import that the age of Reformation was so much characterised and even centralised surrounding divergent interpretations of the Eucharist. This was precisely because this sacrament exemplifies the paradox of incarnation. Christ really is present in the elements even if the elements are only bread and wine. This is a simple statement regarding a profound mystery. Reformers such as Luther, Zwingli, and eventually Calvin tried to rationalise the mystery into coherent doctrines, but only achieved to gravely and irrevocably contradict one another. A paradox seeks to remain paradoxical. Attempts to resolve paradox only lead to further division and polemic.

A further benefit of honouring the Christian paradox is that ordinary struggling human beings can actually own this incarnational understanding of God. In other words, disciples of Jesus can actually serve as a reflection of Jesus to their fellow human beings. Not that this is to be taken lightly. This level of discipleship might come at great cost as Bonhoeffer has shown in his own life and ministry (see Eberhard Bethge 1979). Christianity as a path of discipleship blurs boundaries like nothing else.

Undoubtedly there are numerous credible examples in South Africa of exactly the kind of grassroots incarnational theology that could serve as a model for what could in fact be held up as a ray of light, as a hopeful beacon in the midst of the seemingly constant flow of news stories focusing on the greed, corruption, sexual misdeeds, and bad ethics of political and church leaders. The example on which I shall focus as a case study in this paper concerns the TLF, a Christian inspired NGO that has been operating in the Pretoria/Tshwane inner city since the early 1990s. Although I shall refer to the TLF in more detail below, I can briefly state that their work concerns the empowerment of people in the inner city who are often 
at risk from conditions of unemployment, homelessness, prostitution, HIV and AIDS, abusive relationships, substance dependencies, and so forth.

Although they are not a church in any conventional sense, they connect to various inner city churches as well as other Christian and secular organisations in their efforts of 'creating spaces' of hope. Evidently they do not see themselves as a charitable organisation, but rather as facilitating the already existing stories of hope in places and amongst people where outsiders would usually expect to find only hopelessness and despair. The TLF is not a church, but do they perhaps more closely resemble the Pauline body of Christ than many conventional churches? It seems to me that their activities have sacramental connotations in the inner city, which, when given some consideration, may prompt theologians to reconsider their own views of ecclesiology. ${ }^{1}$ Not only do the activities of the TLF serve as symbols of God incarnate, they embody a community's hope for the kingdom of God. More on the TLF will follow below.

\section{The sacralisation of authority as opposed to incarnation}

To briefly explain my thesis regarding these concepts for the purposes of this article, incarnation and sacralisation both refer to situations where the secular and the sacred crossinfuse the other. The sacralisation of power refers to cases where otherwise mundane processes of society, such as politics or the market economy, become conceived in quasireligious terms, thereby entering the terrain of the sacred. It might also designate the tendency to deify figures of power. Incarnation (or more intentionally incarnational and sacramental theology) on the other hand refers to a situation wherein the sacred self-identifies with the mundane concerns of ordinary people. The former seeks to vest sacred power in structures of authority; the latter is concerned with the empowerment of disenfranchised humanity, both spiritually and materially. The connection to the sacramental is that in the Eucharist, God does not only become human in Christ, but also transforms, whether symbolically or not, into the bread and wine that nourishes humanity.

A further reason for including the theme of the Eucharist in discussions of incarnational theology is that interesting things can happen when food and religion mix. It concerns the issue of taboo and becomes a stumbling block for some as had happened to both Peter and Barnabas amongst others, according to Paul in Galatians 2:11-13. The theme of eating together with the 'other' retains its controversial aspect in more recent times as I will show below. This theme can, however, also serve as catalyst for transformation, thereby clearly illustrating a sacramental potential.

\footnotetext{
1.The sacramental theology of Edward Schillebeeckx (2012) might help us here Stephan van Erp, for example, writes: 'As [Schillebeeckx] saw it, theological renewal was and always will be a necessary response to the ongoing presence of Christ among us, the ever-anew sacramental encounter with God. This means in my view that the incarnation should be regarded as the starting point of his theology and its sacramental character as the key motivation of his theological hermeneutics' (Van sacramental characte
}

Sacralisation and particularly the sacralisation of authority in southern African contexts will now be considered in greater detail.

During the apartheid era the sacralisation of authority occurred to a degree through what has been described as Afrikaner civil religion (Bosch 1986; Moodie 1975) in the sacrosanct status that was awarded within the Afrikaner community to the workings of the state, which was allowed to commit all sorts of abuses of human rights without much challenge or criticism from the silent majority, including the Afrikaner reformed churches. A legendary master narrative of Afrikaner chosenness and God-instituted separateness served this sacralisation of authority quite well (see Kinghorn 1986:86-116). Internal critics of the master narrative were derided as volksverraaiers, heretics to the joint causes of Afrikanerdom and white supremacy.

Prominent examples of such heretics include the name of the well-known Beyers Naudé, but one could also mention the case of a dissident Afrikaner missionary who experienced a great deal of ostracism from within the inner circle of Afrikanerdom after his rejection of the sacred cows of nationalism and white supremacy. This was Nico Smith, whose friend and biographer, Willem Saayman, aptly named him 'die beroerder Israels' (Saayman 2009).

The interesting thing about Smith was that one of the catalysts that helped to crack the fissure of his formerly unshakable adherence to the master narrative of Afrikaner nationalism concerned an interracial gathering around a communal meal in his mission field in Vendaland in the late 1950s early 1960s. Although his biographer did not date the event it was described as a crucial memory that eventually inspired change. This concerned a meal that Smith at the time refused to participate in, a refusal which would come back to haunt him in subsequent remembrances as he increasingly came to question his formerly unquestioned presuppositions. What happened at the time was that a German Lutheran missionary invited Smith to an ecumenical dinner meeting. Upon arrival Smith discovered that there were a number of people present, missionaries as well indigenous pastors. When all made ready to sit down together at the dinner table, Smith could not join them. He had been so steeped in the ideology of Afrikanerdom that the idea of sitting down for a meal together with black Africans was completely anathema to him. He explained his objections to the German hosts and so they laid out a table for him in an adjacent room. There in his selfimposed solitary confinement Smith proceeded to have his lonely meal, perhaps for the time being satisfied in the sure knowledge that he had thereby shown his loyalty to what was evidently his unacknowledged primary reference group, white Afrikanerdom.

Yet, as time had progressed, the memory of this experience and his own choices within the situation would gnaw at Smith's consciousness. The whole story of Smith's eventual apostasy to Afrikanerdom and conversion to inclusive Christianity 
cannot again be recounted here (see Smith, 2010), but I wish to emphasise the implicitly sacramental connotations of the above-mentioned meal in an apartheid South Africa context. Extraordinary as it may appear now, it should not surprise that Smith who was a Dutch Reformed missionary at the time refused to partake in this interracial meal. The taboo against eating and drinking together, especially alongside the communion table, but also for mainstream Afrikaners in more secular settings, had for long been a cornerstone of the sacralisation of white separateness.

Sacralisation of authority, however, not unlike Joseph's coat of old, comes in many colours. Collium Banda and B.B. Senokoane have written an insightful 2009 article on this theme in relation to Robert Mugabe's Zimbabwe. The authors argue that although Zimbabwean Christianity has grown phenomenally in recent times, this growth is directly implicated in the political repression under Mugabe's rule.

More particularly, the tendency within some Zimbabwean churches to sacralize the authority of church leaders combined with a misrepresentation of Romans 13:1-5 has led to an increase in political repression in Zimbabwe'. (Banda \& Senokoane 2009:208)

The authors speak of a crisis in Zimbabwe, but also elsewhere in Africa regarding churches' tendency to legitimate a status quo of authoritarian rule:

In Zimbabwe the crisis consists in the tendency to sacralize the authority of church leaders, especially the founder leaders in some leading churches, which has subtly supported political repression by sacralizing political authority, and disabled the Christian community to actively resist repressive leadership ... [C]hurches do influence and shape society and culture. And certainly, the church's ideas on leadership have influenced the political situation in Zimbabwe. (Banda \& Senokoane 2009:213-14)

The sacralisation of authority that is now being perpetuated by some churches is however something that was also partly inherited from the pre-colonial past as the above-mentioned authors point out:

In traditional Zimbabwean societies chieftainship was inherited, and once the chief was installed he remained in that position for life since the installation for chieftainship depended on the sanction of the ancestral spirits and God. (Banda \& Senokoane 2009:215)

Anyone who has heard Robert Mugabe indignantly speak about being Zimbabwe's rightfully elected ruler during the past several years, despite numerous claims to the contrary, cannot fail to recognise something of a pattern of resemblance when it comes to the above description of traditional rule. According to Banda \& Senokoane (2009:216) 'it needs to be understood that in traditional African thinking leadership, religion, and the community are all intertwined within a collective whole'. They furthermore state that although Mugabe has not been furnished with titles of divinity, certain old Christian hymns have been reworked to specifically honour Mugabe, including, "'Who is He In Yonder Stall" and the chorus "Hakuna A kaitasa Jesu" (translated, "There is none like Jesus") ...' (Banda \& Senokoane 2009:216).

This explains why supporters of the opposition could be persecuted with impunity. It is not merely a matter of differences of opinion regarding policy matters, as uninformed outsiders might be tempted to think; 'when authority and leadership are sacralized, rivals, critics and voices of dissent are ultimately turned into evil forces that are in opposition to God's purposes' (Banda \& Senokoane 2009:220). It also explains why Mugabe seems to be so successful in stigmatising his political opponents as puppets of the British and Americans. Such claims echo and reinforce a deep-seated:

popular Zanu-PF sentiment that to be critical of Mugabe and the party is to be un-African. Voices of dissent are viewed as the agents of the West's regime change agenda. (Banda \& Senokoane 2009:226)

After the most recent 'election' this situation more or less continues to be the situation in Zimbabwe. However, we cannot close this theme of the sacralisation of authority without mentioning the fact that the current government in South Africa is also, troublingly, not immune to this trend. Banda and Senokoane mention the case of Jacob Zuma, about whom there might be a perception within the culture of the African National Congress (ANC) of not being entirely subject to the laws and norms of society that bind lesser South African mortals. Zuma was for example explicitly linked to Jesus by the Free State Premier, Ace Magashule, who stated: 'In church they sing that that [sic] they will follow Jesus wherever he goes. That's how we should be about Jacob Zuma' (Banda \& Senokoane 2009:226). This connotation has on a number of occasions been extended to include the entire ANC, perhaps most notably when, pre-Nkandlagate, a still highly confident Zuma himself confidently predicted that the ANC will rule in South Africa until the second coming of Jesus (Mkhwanazi 2008). Of course, if Zuma was indeed Christ returned as implied by Ace above then this statement is a tautology! Many will argue that Zuma's presidency has been characterised by so much scandal that any Christ-like connotation is nothing short of blasphemous, but as Dale Mckinley points out, the ANC, which has always had strong Christian connections, really upped the ante regarding religious symbolism under Zuma's leadership. Assurances of heavenly rewards for party loyalty are seemingly routinely given as are dire warnings against the spiritual implications of dissent (McKinley 2013).

The above will suffice as examples of poor public theology with respect to human-divine border-crossing attempts. I now turn to a discourse that is wholly more interesting and promising for the dignity of our common humanity.

\section{The TLF as model for sacramental living or incarnational theology}

My attention became focussed on the TLF when I was invited to participate in a 'meal of peace' in mid-August 2013, hosted by the University of South Africa (UNISA) in collaboration 
with the TLF, with the principle to bring together academics and homeless people as well as staff and volunteers from TLF around, literally, round tables. A huge banquet was laid out and whilst some speeches were made the real value of the event was undoubtedly the fellowship that ensued between people whose paths would not ordinarily cross. Communal eating affirms common humanity just as the Lord's Supper affirms communion with God amongst people.

Shortly after this meal I noticed a newspaper article, in which Dr. Stephan de Beer who was until recently the MD of the TLF (Jackson 2013:15) was interviewed. In the article De Beer made a number of statements, which made me wonder whether their approach could be seen as an antidote to the above-mentioned depressing stories of unsavoury sacralisation?

Undoubtedly the TLF is a good story about the affirmation of human dignity in the midst of border crossings of various kinds. The newspaper article elaborates on the equalising nature of many of their activities, things that involve eating and playing together. Stephan de Beer and the majority of the TLF staff members live in the inner city, a place that had been abandoned subsequent to the end of apartheid by most whites with the financial means to move to the suburbs.

In the article, De Beer directly connects their work at TLF to the incarnation of Jesus. For example, one of their projects, called Gilead, is a hospice for terminally ill homeless people. It is also a home for people with mental illness who would otherwise find themselves on the streets, as well as a centre where people could have themselves tested for HIV and receive counselling, if needed. De Beer states that when he thinks of church, he thinks of Gilead. On the other hand, he does not feel at home in the type of 'church' where people sit behind one another in pews.

Stephan de Beer was recently appointed as the director of the University of Pretoria's Centre for Contextual Ministry. Wilna de Beer, who has also been intimately involved in the formation and development of TLF, now serves as MD of the TLF (Jackson 2013). It was with her help that my own meeting at the TLF office was arranged, once I came to realise that there could hardly be a better case study to illustrate what I wanted to say about sacramental living, or following the model of the incarnation.

Our first meeting took place on 06 September 2013 at the TLF offices in Burgers Park Avenue. Although I had come prepared with some general questions, such as, 'how and why did you become involved in TLF?'; 'what makes you either hopeful or filled with despair when you think about your work?'; 'what is the relationship between TLF and churches?', and so forth, the session proceeded more or less as a semi-structured interview. Participants freely interrupted one another, commented on others' comments, and offered their opinions whenever they felt like it. I did at the beginning inform them about the nature and theme of the conference for which I wanted to use the interview data, and I asked them to specifically keep in mind the issues of human dignity and crossing of borders in the way the discussion proceeded.

What follows is my interpretative retelling of what I heard from staff members and participants at the TLF. In response to an opening question about what they consider to be their main ministry, the following was stated by one staff member working at Potter's House, a home for at-risk women and their children:

'We are restoring women's dignity. We journey, we listen to people, we don't judge. We create space for women, space for dialogue so that they can at least talk about their issues and make sense of what has happened to them ... We foster togetherness in the spaces. It is not about doing things for the community or people in need, rather it is about being on a journey with people. Along the way we facilitate and uncover their potential. They develop their own potential. We only create the spaces for women to participate together in these spaces'.

There occurs a process of mutual learning; 'we are all in need of some kind of healing. Through the activities of TLF everyone together can get healing. We are together in healing'.

Can South Africans reconcile? I asked this question that I overheard at a recent conference I attended, in which a speaker questioned whether we should talk about reconciliation in South Africa given the fact that power relations had been drastically skewed ever since the onset of colonialism. This was one of the (black) staff members' response:

'That would be like an insult to our process immediately after our democratic period started. If the TRC did not happen the damage would be even worse. That was a very wonderful beginning to the healing process. Reconciliations should happen, because it is not only between white and black, but also within race groups. When human dignity is emphasised then reconciliation is non-negotiable'.

In response to a question on how they see human dignity the following was emphasised: 'Human dignity is the common ground, which we all share'.

During the interview we were sitting around a roundish table, and so one of the participants mentioned that this is the way they always do things at TLF. The round table is symbolic of TLF and emblematic of the equalising approach they seem to take in all matters.

A different participant, who is a pastor with a theological background, drew the link between human dignity and being created in the image of God. He emphasised the creativity of human beings as inherently connected to the issue of human dignity:

'Human beings are creative because they are created by God. Therefore we should respect the other person too because of imago Dei. In human dignity you don't respect someone for what they have but for who they are as created in the image of God'. 
In response to a question about whether TLF could be considered a 'church' in some ways, the following was said with complete affirmation by other participants:

'TLF is a movement. A church in the street - TLF is a street church. A church without walls, a church that is very accepting, not judgmental. People can accept God without preaching. People say, 'This is for me my church.' As the biblical James said, a church is something that takes care of the widows and the orphans'.

Another participant observed that the people they work with often say that they have no need of going to or belonging to more conventional churches on Sundays, because TLF is their church. Methodologically, the TLF follows the pastoral cycle, which is a praxis model of community engagement, emphasising mutual reflexive action and learning. They see themselves as representing the household of God.

On the history of TLF it was said that they 'tried to be like the hands and feet of churches'. Out of the church and into the streets was the motto. Some years went much better than others; 'We had ecumenical services, etc., but that is rather dead now'. Regarding their relationship to conventional churches, it was mentioned that when they started in the early 1990s their goal was to serve the churches by engaging in ministries, which the churches themselves were not prepared for and not equipped for dealing with. Although they have since become a self-supporting NGO, they maintain similar relationships with churches:

'Half open, half not open is the way churches tend to relate to TLF. Many churches now, some with lots of money, try to do what TLF does, not bothering about replicating services, but perhaps because of their financial strength not interested in seeking partnerships with people. Suburban churches come in to 'save the city'. They also what to keep themselves 'clean.' No sleeping on their lawns, for example. They even put on sprinklers to get [homeless] people to leave'.

My question about what makes them either despair or hopeful elicited some very interesting responses. On the despair side it became apparent that the city structures, in particular the metro police, are working from an ethos directly contradictory to the assumptions of the TLF regarding human dignity. It was mentioned, for example, that a number of street hawkers who were known to staff members at the TLF for 20 years had suddenly disappeared, having apparently been 'cleaned up' (forcefully moved to a ghetto-like out-ofsight location in a different part of the city). At the time of our meeting they were still trying to understand at TLF why this was happening. It became apparent that there were radically different ideas about what a healthy city should look like. From the TLF's perspective people might have a preference for living on the street, and if so, that should be respected.

The metro police, on the other hand, try to prevent street living; 'they even take homeless people's merchandise and then they end up having nothing, so they return to TLF and the whole empowerment process has to be repeated again'. Apparently there is a procedure from the side of the municipality, which wants people to register and apply for licenses to sell their things:

'The city advertises this as a wonderful development, but in effect this is just bureaucracy, because in the meantime people are disenfranchised and prohibited from selling their stuff. What is so ironic about this is that our mayor even confessed that his own mother was working as a street hawker who sold things on the streets ... Our mothers are sitting out there selling things till 2 in the morning just to keep their kids in school. This means that they develop a lot of practical knowledge, but they are never consulted. We can never talk between structures and this in effect leads to an escalating crime rate. TLF breaks down these barriers, but this is not a reality for other interest groups. Despite the fact that there exists a lot of practical knowledge on the streets, the people in the municipal structures never bother to talk to people on the streets. They just make top-down decisions'.

A disturbing analogy was drawn between the process of garbage removal and the way these mentioned city structures deal with the homeless, who are seen as dirt, according to my respondents. As mentioned above they are 'cleaned up' from the streets, and then disposed of in some unseen places where they are more or less left to rot. There are apparently no services or community workers in the murky places allocated by the city, which, according to my respondents, resemble refugee camps:

'Struben no. 2 is the place where people are taken to ... It literally looks like a garbage dump. The streets are clean yes... They take all their belongings away from them, some of these people are mentally ill. Broken, completely broken ... Home Affairs are trying to deport people. However you cannot arrest pregnant women, so they bring them here, but afterwards they try to deport them with their children. But this is just hopeless, because these people have nothing back where they are from so they just end up coming back here. The whole thing is just a waste of money. The metro police come and take all their stock, so these people are without anything. Asylum seekers end up being criminalised by the system. If I am denied asylum my kids become criminals effectively'.

Migrants, many of whom the TLF deals with, are particularly vulnerable in terms of this system.

'We believe to look at every person through the eyes of God. Your papers, your skin colour, etc., should not be a barrier. We try to work with every individual and listen to your story. We do not say no. But we need a platform to address this issue with the city government. The government however has no strategy to deal with this issue'.

Viscerally angry at this out-of-sight, out-of-mind treatment by the city of the homeless, one staff member stated: 'I will take all my shacks from Salvokop and build it on Jacob Zuma's land!' Perhaps an unrealistic threat, but no doubt there are some bones of contention regarding perceived inequalities and abuses of rights. At the TLF people are clearly very passionate and not afraid to voice their disagreement with government policies. Hopeful signs from the perspective of the TLF seem comparatively slim. However, one positive thing that was mentioned was that people in South Africa are perceived to be increasing their awareness of social issues. 
They are more interested in giving and volunteering, and so forth. This includes churches that show much more interest in being involved in the inner city.

However, within the churches too, there are tensions. I was told that churches sometimes appear to think that they know all the answers, and that they know which needs exist and how to respond to them. There is a perception that churches often go about their business in the city without really consulting the networks of knowledge existing in the TLF.

'The churches do not take hands with us. They do things for the congregation. They give things, which is great of course, but do they really know how much they can actually do?'.

The churches seem to operate from a charity culture, which is not perceived as all that helpful. For example, "The churches give blankets, but when you give blankets you don't empower someone.' The TLF on the other hand focuses on skills development, advocacy, training, etc.

The government gives money, but then they want to control the agenda.

They want us to dance to their tune ... For city housing you must apply with a green ID book, so what happens to the rest of the people? A green bar-coded ID book is what you need. So, so many people are falling through the cracks. How can we (South Africa) be at the G20, which is a globalised organisation if our policies are so exclusive?

The TLF pre-supposes an ethos of brokenness and imperfection. Implicitly they completely identify with Bonhoeffer's 'suffering God'. Everybody needs healing.

In response to a question of how they became involved in the TLF a discussion ensued that climaxed with the memorable line: 'We either come in broken or we break along the way.' Also, regarding the way they think about their work, it was stated that it was not a job that you come in and do. Emphasising the typically hands-on, holistic approach one person stated: 'I live my job.'

Why do they work there? The theme of calling is specifically mentioned and emphasised in the responses. One woman only wanted to do administrative work whilst being a mother to a young child, but her curriculum vitae $(\mathrm{CV})$ drew more attention than she had bargained for. She became involved in HIV-related issues, although she did not really have the proper paperwork. Now she feels 'called', and she is happy. If she goes to bed angry, she wakes up with something that provides a key to the solution. 'We break along the way ... It becomes a life. It is a passion. I live it, I eat it, I sleep it, I dream it'.

However, in spite of a sound philosophy it seems that even at the TLF it is difficult to not feel overwhelmed sometimes. One younger staff member lamented the fact that she helps people, but it never proves to be enough and often she is unsure of when and where to stop. She is worried about creating a dependency syndrome. As this conversation developed a senior member stated that for this and also in cases of violent or troublesome persons the TLF has their own structures and policies to fall back on. For example: it is policy that they do not help people who harm others or themselves. Some people furthermore just cannot be helped; 'Let your no be a no and your yes be a yes'. On the other hand:

'... sometimes it may seem that someone is not willing to change, but God might be working there even if you do not see the fruits

... Sometimes it is necessary to simply refer a person to God'.

At this point the interview more or less unravelled as participants started to counsel one another about the issues just discussed. I found this symbolic of the round table ethos in that the agenda in this conversation clearly did not belong to me who was ostensibly in charge of the process.

'Maybe we should keep on having nothing'. This was stated to emphasise the need to fully identify with the people they work with; 'I just go to them. I'm like you. I have nothing'. This approach resonates in the city as evidenced for example by an anecdote told that at one stage one of the homeless people even offered some of his belongings to the TLF people during a project.

One of the homeless people present at our meeting ventured the opinion that perhaps people should not be given too much freedom of choice; 'for example when you're in a desert you can even drink urine'. What is this all about? 'It's about doing things together. It's not about quick fixes. People can solve their own problems, but they need togetherness to actually carry it through'.

On the issue of intentional border crossings it was stated that strategic action and thinking is needed. For example: expose people from the eastern suburbs, who are also broken in their own way, and bring affluent students from the University of Pretoria to the inner city. It is the TLF's experience of these types of border crossings with students that it is often a ground-shaking and eye-opening experience for students from suburbia to be exposed to the life in the streets of the city. They are humbled to see how people can survive out of apparently nothing.

The meal of peace, which I participated in a couple of weeks earlier at the University of South Africa (UNISA), was furthermore mentioned as a powerful border crossing ritual.

When I returned for a second meeting on 28 November 2013 in order to report back regarding my conference presentation, we particularly discussed the wider themes of sacralisation of power, and the idea of the TLF as a church. These were amongst the themes that drew particular attention from conference participants, which included theologians from the Netherlands. ${ }^{2}$

2.Stellenbosch - Protestanste Theologische Universiteit consultation, "Crossing Borders, Conflicting Loyalties,' 28-29 October 2013 at Stellenbosch University, South Africa. 
Much of the conversation revolved around the TLF's positioning vis-à-vis the 'powers' in the city, namely various embodiments of the municipality and provincial government. It became clear that they had to tread a very fine line with respect to these powers. Although much of what happens is intolerable for the TLF's clients, who often suffer assaults on their human dignity, TLF is also conscious of the fact that they need the city structures as partners in order to make positive contributions. It was in the light of this dilemma that an intriguing metaphor of 'sheep dancing with wolves' was used.

In spite of the fact that the TLF undoubtedly represents the sheep in the above metaphor, this is fully appropriate within the context of the point I am making about their incarnational theology; in discipleship of the lamb of God. Their vulnerability is backed up by much street knowledge and crucially the willingness to keep on pressing the boundaries.

One area in which boundaries might still be further pushed concerns the self-conceptualisation of a group such as the TLF as not only like a church, but in fact a church. Mention was made of the Church of the Saviour in Washington DC as a good model for the TLF in that the former's ministry style, which is community and inner-city centred, corresponds with what the TLF is doing. There is perhaps a Pharisaic tendency in some of the established churches, especially in their views on 'cleanliness' and its connection to holiness that need to be challenged. In illustrating this point the MD recounted receiving a letter from a homeless person who wrote about wanting to go to church on a Sunday, but not going in the end. Being 'dirty' and not having clothes, this person probably correctly assumed a less than warm welcome might be expected at the church doors. This is where TLF presents a truer picture of holiness, more closely aligned with what Marcus Borg has for example shown as characteristic of the synoptic Jesus. Borg contrasted the biblical themes of purity and compassion and showed convincingly that a discipleship of Jesus and the early Christian community would require a politics of compassion (Borg 1995).

The concluding sentiments of the participants seemed to be that although TLF might indeed be like a 'city on a hill' or a 'lamp on a table', especially to those homeless who depend on them so much, much more worked remained for them to truly become 'agents of change' that could break down the idolisation of power, and that could truly challenge the flawed character of this deeply divided city.

\section{Conclusion}

In conclusion I would like to return to the meal of peace that served as the original catalyst for my delving deeper into the TLF. It is especially the idea of the meal and what it symbolises that seems important. Communal meals in Christian encounters have a special meaning. Where people eat together common humanity is affirmed and the sacralisation of power relations becomes subverted. That is why a yet un-reconstructed Nico Smith could not participate in such a meal in Vendaland. But communal meals can be symbolic of sacramental living such as represented by the TLF, even when such living is non-triumphal, broken, and often scant on hope.

Some of the TLF staff are pastors and people with a theological training, but many of the others have no formal theological background. What I see as their grassroots incarnational theology is therefore not explicit or systematically worked out. To the contrary, this exists and is embodied within their active participation in the broken lives of the inhabitants of the inner city. Much like the sacramental bread and wine of the communion table, the TLF members might not even be consciously aware that interpreters of their role are tempted to draw direct connections between them and the body of Christ. Yet, they are aware of their brokenness as the above description indicates. This is an awareness that is aptly analogous to the broken bread of the sacrament, and the broken body on the cross to which it points.

Organisations such as TLF are, however, not important in terms of what they might point to, but rather in terms of what they actually represent, which is incarnational theology in the midst of fragile humanity. This is why I related my interaction with staff members and homeless at the TLF in a more or less 'raw' format. As such it constitutes elements of the broken, yet evolving history of a Christian encounter in the post-apartheid inner City of Tshwane.

Is their story an antidote to the more depressing stories of sacralisation which I touched upon? I am not sure, but at least it is a story worth telling, because embedded as it is within the emerging story of Tshwane, it is no less quintessentially African than those other more familiar stories.

\section{Acknowledgements}

I would like to express my appreciation to everyone at the TLF who have shared their time and thoughts with me in preparation for this article, especially the managing director, Wilna de Beer.

\section{Competing interests}

The author declares that he has no financial or personal relationship(s) that may have inappropriately influenced him in writing this article.

\section{References}

Aquino, F.D., 2000, 'The Incarnation: The dignity and honor of human personhood', Restoration Quarterly 42, 39-46.

Banda, C. \& Senokoane, B.B., 2009, 'The Interplay between the Christian sacralization of human authority and political repression in Zimbabwe', Religion \& Theology 16 207-245. http://dx.doi.org/10.1163/102308009X12561890523636

Battle, M., 2009, Ubuntu: I in you and you in me, Church Publishing, Inc., New York.

Bethge, E., 1979, Prayer and righteous action in the life of Dietrich Bonhoeffer, Christian Journals, Belfast.

Borg, M.J., 2009, Meeting Jesus again for the first time, HarperCollins, New York.

Bosch, D.J., 1986, 'Afrikaner civil religion and the current South African crisis', The Princeton Seminary Bulletin 7, 1-14. 
Brown, D., 2006, 'Four Gods of Christian faith', in The evolution of rationality: Interdisciplinary essays in honor of J. Wentzel van Huyssteen, pp. 294-305, Eerdmans, Grand Rapids. http://dx.doi.org/10.1111/zygo.12014

Fergusson, D., 2013, 'Humans created according to the Imago Dei: An alternative proposal', Zygon: Journal of Religion \& Science 48(2), 439-453.

Jackson, N., 2013, 'Kommentaar en ontleding: Kombers van stadsafval', Beeld besigtig 24 April 2014, by http://www.netwerk24.com/stemme/2013-08-19kommentaar-en-ontleding-kombers-van-stadsafval?vc=3a651ecbb870e76fd819 $74 f 63 b c 3240$

Johnson, E.A., 2011, Quest for the living God: Mapping frontiers in the theology of God, reprint edn., Bloomsbury Academic.

Kinghorn, J., 1986, 'Die Groei van ' $n$ Teologie - van sendingbeleid tot verskeidenheidsteologie', in Die NG kerk en apartheid, pp. 86-116, Macmillan, Johannesburg.

Koyama, K., 1999, Water buffalo theology, Orbis Books, Maryknoll.

McKinley, D.T., 2013, 'Zuma and the ANC's God complex', viewed 24 April 2014, from http://sacsis.org.za/site/article/1634

Mkhwanazi, S., 2008, 'ANC to rule until Jesus comes back', viewed 03 Decembe 2014, from http://www.iol.co.za/news/politics/anc-to-rule-until-jesus-comesback-1.398843\#.VH7UHjGUd1U
Moltmann, J., 1993, The crucified God: The cross of Christ as the foundation and criticism of Christian theology, 1st edn., Fortress Press, Minneapolis.

Moodie, T.D., 1975, The rise of Afrikanerdom: Power, apartheid, and the Afrikaner civil religion, University of California Press, California.

Saayman, W.A., 2009, Die beroerder Israels: 'n Biografiese waardering van Nico Smith, Publiself Uitgewers.

Schillebeeckx, E., Borgman, E., Murray, P.D. \& Torres Queiruga, A. (eds.), 2012, Sacramentalizing human history: in honour of Edward Schillebeeckx (1914-2009), Concilium SCM Press, London.

Schwöbel, C., 2006, 'Recovering human dignity', in R. Kendall Soulen \& L. Woodhead (eds.), God and human dignity, pp. 44-48, Eerdmans, Grand Rapids.

Smith, N., 2010, Die dood van die God van my vaders: Hoe die lewe in die township Mamelodi my godsbeskouing verander het, 1ste uitg., Griffel Media, Kaapstad.

Soelle, D., 1984, The Strength of the weak: Toward a Christian feminist identity, 1st edn., Westminster John Knox Press, Philadelphia.

Van Erp, S., 2012, 'Incessant incarnation as the future of humanity: The promise of Schillebeeckx's sacramental theology', in Sacramentalizing human history: In honour of Edward Schillebeeckx (1917-2009), Concilium, SCM Press, United Kingdom. 